\title{
СУЧАСНІ УЯВЛЕННЯ ПРО ВАРІАНТНУ АНАТОМІЮ ГІЛОК ДУГИ АОРТИ (ОГЛЯД ЛІТЕРАТУРИ)
}

Вищий державний навчальний заклад України «Буковинський державний медичний університет», м. Чернівці

Резюме. Літературне дослідження свідчить про виражену індивідуальну та вікову анатомічну мінливість гілок дуги аорти. У статті наведені відомості про уроджені деформацію і звивистість дуги аорти, атипові та рідкісні варіанти топографії ії гілок, унаслідок чого можуть виникнути компресійні симптоми, порушення кро-

У структурі кардіоваскулярної патології новонароджених i дітей першого року життя 65-70 \% займають уроджені вади розвитку серця і судин [16]. Сучасний етап ангіохірургії характеризується широкими діагностичними можливостями, пов'язаними з розробкою селективної вазографії, а також використанням різних видів протезування та шунтування судин. При описі варіантів відходження артерій від «материнської» судини акцент, як правило, робиться на класичний варіант початку. У той же час знаходження артефакту у вигляді рідкісного варіанта галуження судини, не описаного в підручниках або посібниках, може вартувати навіть життя хворого. Слід зазначити, що гілки, які аномально відходять від дуги аорти, можуть деформуватися чи стискатися суміжними органами, що призводить до порушення кровопостачання відповідних ділянок.

Досліджено і вивчено досить велику кількість варіантів дуги аорти і їі гілок. Така різноманітність пов'язана з порушенням розвитку аорти. Часто варіанти розвитку дуги не призводять до порушень кровообігу, але в деяких випадках трапляються такі аномалії, які супроводжуються патологічними змінами [19]. Якщо при типовому варіанті будови власне дуги аорти, іiі гілки можуть розгалужуватись як класично, так і некласично, то атипові варіанти дуги аорти практично завжди супроводжують некласичні розгалуження iї гілок. Д. Лужа [10] виділяє наступні варіанти дуги аорти:

1) нормальний варіант, за якого аорта і всі судини, що беруть від неї початок, розташовуються зліва. Цей варіант трапляється у 83-85 \% випадків (Adachi, 1928, Pontes, 1963);

2) близький до нормального варіант, коли топографія дуги аорти та іiі гілок є типовою, але низхідна частина аорти знаходиться ліворуч i позаду стравоходу (Edwards, 1948; Grob, 1949). Слід зауважити, що на місці перетину стравоходу 3 низхідною аортою формується втиснення (Franke, 1950). Відхилення вправо трапляється високо на рівні дуги або позаду роздвоєння трахеї. При такому варіанті права підключична артерія або плечо-головний стовбур іноді відходять як остання гілка аорти від місця початку низхідної аорти;

(C) Т.В. Хмара, Н.О. Базік, Л.Я. Лопушняк, 2016 вопостачання відповідних ділянок. Можливість атипового розташування гілок дуги аорти слід враховувати при проведенні хірургічних втручань, оскільки при цьому виникає висока вірогідність їх пошкодження.

Ключові слова: дуга аорти, топографія, варіантна анатомія, людина.

3) правобічна дуга аорти, коли остання розташовується $з$ правого боку. Якщо низхідна аорта йде у правій половині грудної клітки, то виходить ऑï дзеркальне відображення. У такому випадку гілки відходять нормально або змінюють свій порядок (Fray, 1936; Thurnor, 1951). Знаходячись позаду стравоходу, плечоголовний стовбур або ліва підключична артерія разом із висхідною аортою оточують трахею і стравохід (Grollmann и др., 1968), внаслідок чого можуть виникнути компресійні симптоми;

4) правобічна дуга аорти з вигином, коли низхідна аорта повертає вліво і проходить між хребтом і стравоходом. Аорта може проходити між трахеєю і стравоходом (Grob, 1949; Almos et Lonyai, 1962). Виникає складний потрійний вигин аорти. У такому випадку дуга аорти може розташовуватись вище яремної вирізки (Bender et al., 1964). Відходження гілок має багато варіантів. На рентгенограмі гирло аорти візуалізується справа, а низхідна частина зліва;

5) відсутність дуги аорти. Висхідна частина аорти починається 3 лівого шлуночка, а низхідна - являє собою продовження артеріальної протоки, таким чином, дуга аорти не визначається (Adachi, 1928). Це означає часткову транспозицію аорти;

6) стеноз перешийка аорти, що являє собою часткове звуження ділянки перешийка аорти і призводить до порушень кровообігу, вважається аномалією.

Окремі автори [7] при дослідженні 20 трупів людей різних вікових груп (45-75 років) виявили індивідуальну мінливість гілок дуги аорти та описали три рідкісні варіанти початку ії судин. У першому випадку плечо-головний стовбур відсутній, а безпосередньо від дуги аорти відходило 6 артерій: права і ліва підключичні артерії, права і ліва загальні сонні артерії, права і ліва хребтові артерії. У другому спостереженні виявлена правобічна дуга аорти з аномаліями розвитку судин. У третьому випадку від дуги аорти починалися артерії загруднинної залози і три м'язові артерії.

О.А. Горустович и др. [4] описали ще один некласичний варіант відходження гілок дуги аор- 
ти. Справа наліво від дуги аорти брали початок чотири судини: права і ліва загальні сонні та ліва і права підключичні артерії. При цьому права підключична артерія відходила позаду лівої однойменної артерії на відстані 10,0 мм.

У структурі серцево-судинних захворювань частота уроджених деформацій дуги аорти становить 0,4-0,6 \% [15], проте справжню частоту аномалій дуги аорти встановити тяжко, оскільки без супутньої патології серця вона часто проходить безсимптомно [11]. Деформації дуги аорти класифікують залежно від: 1) топографо-анатомічного типу дуги аорти (правобічна, лівобічна); 2) виду деформації (подовження, звивистість, петлекільцеутворення, перегин); 3) локалізація зміненого сегмента дуги аорти (між плечоголовним стовбуром і лівою загальною сонною артерією, між лівою загальною сонною і підключичною артеріями, у ділянці гирла лівої підключичної артерії, у місці початку грудної частини аорти); 4) комбінації цієї аномалії з іншими вадами серця, а також із різними вродженими аномаліями дуги аорти (гіпоплазія, звивистість загальних сонних, підключичних, хребтових артерій); 5) розміщення дуги аорти відносно ключиці (шийне, внутрішньогрудне) [2, 11].

В.С. Аракелян и др. [15] описують деформацію дуги аорти 3 клінічної точки зору, зазначаючи, що така уроджена патологія може бути асимптомна, проявлятися коарктаційним синдромом (при вигині), симптомами, характерними для аневризми грудної аорти, або компресійним синдромом. Нерідко трапляється поєднання цих симптомів. Незважаючи на те, що уродженим дефектам аорти в сучасній ангіохірургії приділено достатньо уваги, питання щодо їх термінології та класифікації залишається відкритим. У сучасних наукових публікаціях [9] широко використовуються різні терміни уродженої звивистості дуги аорти: псевдокоарктація, кінкінг, баклінг, мегааорта, лупінг, що характеризуються подовженням, звивистістю і перегинами дуги аорти при патологічній будові стінки. При варіанті «шийної дуги»дуга аорти є видовженою і розташована краніальніше звичайної позиції. «Кінкінг дуги» характеризується виникненням згинів ділянки дуги аорти і проксимальних сегментів грудної аорти. Широко застосовується термін «псевдокоарктація аорти», який означає видовження і кінкінг дуги. При псевдокоарктації аорти низхідна частина аорти, проходячи донизу від перешийка аорти, утворює другу дугу, один вигин якої продовжується у низхідну аорту. Оскільки така зміна будови не супроводжується звуженням аорти, то вона являє собою анатомічний варіант.

Судинні кільця та судинні петлі - це уроджені аномалії дуги аорти і іiі гілок, внаслідок яких порушується їх нормальне розташування в середостінні; аномальні судини оточують стравохід і трахею, стискуючи їх. При судинному кільці трахея і стравохід оточені з усіх боків судинними утвореннями. При судинних петлях трахейно- стравохідна компресія викликана аномальним відходженням однієї із судин від дуги аорти або однією із судин легеневої артерії, що охоплюють стравохід і трахею петлею, що їх стискає [1].

O.А. Мутафьян [11] зазначає, що при подвійній дузі аорти висхідна аорта розташована в передньому середостінні, спереду трахеї і стравоходу, розгалужується на дві дуги: задньоправу i передньоліву, що охоплюють трахею і стравохід 3 усіх боків у вигляді кільця. Задньоправа дуга перекидається через праву легеневу артерію i правий головний бронх, а передньоліва дуга перетинає ліву легеневу артерію і лівий головний бронх. Обидві дуги з'єднуються позаду стравоходу 3 верхньою частиною низхідної аорти, яка прямує зліва або справа від хребта. При цьому від кожної дуги аорти відходять загальна сонна і підключична артерії.

H.A. Alsaif, W.S. Ramadan [17] вказують на те, що у дев'яти випадках $(25 \%) 336$ спостережень артерії дуги аорти мали атипову топографію. У шести випадках $(66,6$ \%) від аорти брали початок дві гілки: першою гілкою (справа наліво) був загальний стовбур, що включав у себе плечо-головний стовбур і ліву загальну сонну артерію; другою гілкою була ліва підключична артерія. У двох випадках (22,2 \%) від дуги аорти (справа наліво) починалися чотири гілки: плечоголовний стовбур, ліва загальна сонна артерія, додаткова гілка, що прослідковувалась як ліва хребтова артерія, і ліва підключична артерія. При цьому хребтова артерія розміщувалася між лівою загальною сонною i лівою підключичною артеріями. В одному випадку $(11,14 \%)$ від дуги аорти починалися плечо-головний стовбур, ліва загальна сонна артерія і спільний стовбур, який включав у себе ліву хребтову і ліву підключичну артерії. Даний стовбур починався дорсальніше лівої загальної сонної артерії.

Окремі автори [22] у 92,72 \% спостережень виявили типовий початок трьох гілок дуги аорти, а також - пять артефактів відходження гілок дуги аорти. При цьому три варіації з пяти були описані вище у літературі [17] і становлять разом 9,02 \% випадків 3 даного дослідження. У $0,90 \%$ випадків описано відходження справа наліво трьох гілок від дуги аорти: плечо-головного стовбура, лівої хребтової і лівої підключичної артерій. Від плечо-головного стовбура атипово починалися три артерії: права підключична, ліва і права загальні сонні артерії. У 0,90 \% спостережень від дуги аорти брали початок лівий і правий плечо-головні стовбури, від яких, у свою чергу, відходили відповідні праві і ліві підключичні та загальні сонні артерії.

Некласичні варіанти розгалуження гілок дуги аорти описує Д. Лужа [10], в яких від опуклої поверхні аорти відходили:

1) лівий плечо-головний стовбур, - спільний для правої і лівої загальних сонних артерій та лівої і правої підключичних артерій; 
2) дві загальні сонні артерії, які починалися спільно від подвійного сонного стовбура, що розташовувався по серединній лінії дуги, а дві підключичні артерії самостійно відходили з обох боків від нього;

3) права хребтова артерія, що починалася позаду лівої підключичної артерії і косо проходила на протилежний бік, при цьому інші гілки дуги аорти мали типове розгалуження (Krause, 1880, цит. Adachi, 1928 );

4) дві хребтові артерії, які брали початок 3 обох боків від лівої загальної сонної артерії, що відходила по серединній лінії; інші гілки мали типове розгалуження.

Також автором зазначаються ще два атипових варіанти, коли гілки беруть початок не від самої дуги аорти:

1. Лівобічна права підключична артерія починається на межі дуги аорти та ії низхідної частини, йде догори, косо направо, позаду стравоходу, іноді між ним і трахеєю (Schmidt, 1957); інші судини самостійно починаються від опуклої поверхні дуги аорти. Такий варіант відомий уже досить давно (Bayford, 1789) і трапляється в 0,5-2 \% випадків (Adachi, 1928; Hayek, 1958), у більшості випадків не викликає суттєвих ускладнень, іноді спостерігаються складності під час ковтання (Holzapfel, 1899);

2. Лівобічний правий плечо-головний стовбур, що $є$ останньою судиною, яка відходить від дуги аорти на межі з низхідною іiі частиною; при цьому інші судини беруть самостійний початок від опуклої частини дуги аорти.

У наукових джерелах [23] ми також виявили ще один рідкісний варіант гілок дуги аорти, в якому було атипове походження правої і лівої хребтових артерій. Справа наліво від дуги аорти відходили: плечо-головний стовбур, ліва загальна сонна, ліва хребтова і ліва підключична артерії. Від плечо-головного стовбура брали початок права загальна сонна артерія і права підключична артерія. Від останньої, у свою чергу, відходили права хребтова артерія. Таким чином, ліва хребтова артерія розташовувалась між лівою загальною сонною і лівою підключичною артеріями. Права хребтова артерія брала початок від правої підключичної артерії в місці розгалуження плечо-головного стовбура.

Окремі автори [24] описали варіант відходження двох плечо-головних стовбурів від дуги аорти, а від іiї задньої поверхні - атипово відходила ліва вінцева артерія. Кожен із плечо-головних стовбурів розгалужувався на відповідні праву і ліву підключичні та загальні сонні артерії.

Дослідження Е.С. Околокулака и др. [12] присвячені віковим особливостям дуги аорти. Після з'ясування скелетотопії дуги аорти зроблено висновок, що з віком вона змінюється не тільки в діаметрі, а й у проекції. Доведено, що чим старше людина, тим дуга аорти проектується нижче. У плодів дуга аорти знаходиться на рівні гирла плечо-головного стовбура, у людей віком
25-30 років дуга аорти проектується на $\mathrm{Th}_{\mathrm{III}}, \mathrm{y}$ віці 40-55 років - на рівні $\mathrm{Th}_{\mathrm{IV}}$, а в осіб після 55 років дуга аорти визначається на рівні $\mathrm{Th}_{\mathrm{IV}}-\mathrm{Th}_{\mathrm{V}}$.

Згідно з віковими особливостями дуги аорти Г.А. Соколов [14] виділив три основні ії форми:

1. Низхідну, що характеризується найбільшою кривизною в місці початку її середнього вигину, далі вона ніби розпрямляється і плавно переходить у низхідну частину аорти. Така форма дуги аорти трапляється, як правило, у плодів і новонароджених людини;

2. Рівномірно вигнута форма, при якій висхідна аорта плавно переходить у дугу, а потім - у низхідну частину. Така форма дуги аорти трапляється як у плодів, так і в осіб до 50 років;

3. Висхідна форма характеризується найбільшою кривизною в дистальній частині дуги аорти, у місці відгалуження від останньої лівої підключичної артерії. Така форма характерна тільки для осіб віком старше 50 років.

Також прослідковується закономірність розташування дуги аорти відповідно до типу тілобудови. В осіб астенічного типу дуга аорти сильно вигнута і знаходиться в косо-сагітальній площині, а в гіперстеніків вона сплощеної форми і розташована фронтально.

Як зазначають А.С. Гусь, Д.В. Шавлюк [8], ділянка роздвоєння загальної сонної артерії характеризується варіабельністю будови, що зумовлено конституційними особливостями черепа людини.

А.Г. Рыбаков и др. [5] зазначають, що у зв'язку з типовою будовою можливі варіанти відходження гілок дуги аорти, а також варіанти їх кількості (від 1 до 8). Аномальні артерії можуть деформуватись, стискатись сусідніми органами, що призводить до порушень кровопостачання відповідних ділянок. Дослідники акцентують увагу на тому, що можливість атипового розташування гілок дуги аорти необхідно враховувати під час проведення хірургічних втручань, оскільки при цьому висока вірогідність їх пошкодження. Дані автори у своїх дослідженнях вказують на некласичні варіанти відходження гілок дуги аорти. В одному випадку від опуклої поверхні дуги аорти справа наліво відходили чотири судини: плечо-головний стовбур, ліві зовнішня і внутрішня сонні та ліва підключична артерії. У другому спостереженні від дуги аорти відходили дві гілки: плечо-головний стовбур і ліва підключична артерія. Ліва загальна сонна артерія починалася атипово від плечо-головного стовбура.

G.L. Shiva Kumar et al. [18] описують ще один рідкісний варіант відходження гілок дуги аорти, при якому від плечо-головного стовбура відходили не тільки права підключична і права загальна сонна артерії, а й права хребтова і ліва загальна сонна артерії. Також від дуги аорти самостійно починалися ліва хребтова і ліва підключична артерії. Автор вважає, що зміни у структурі розгалужень дуги аорти можуть змінити церебральну гемодинаміку, що призводить до певної 
патології. Знання варіантів гілок дуги аорти відіграє важливу роль у діагностиці внутрішньочерепних аневризм судин після субарахноїдального крововиливу.

J.A. Ogeng'o et al. [20] у своїх дослідженнях виявили ще декілька атипових варіантів розгалуження гілок дуги аорти. В одному випадку від дуги аорти справа наліво відходили: плечоголовний стовбур, ліва загальна сонна артерія, ліва підключична артерія, а ліва хребтова артерія починалася дистальніше попередньої. У другому спостереженні від дуги аорти справа наліво відходили: загальний стовбур, що включав у себе плечо-головний стовбур і ліву загальну сонну артерію, ліва надлопаткова артерія та ліва підключична артерія. Від останньої відходила ліва хребтова артерія.

N.L. Mligiliche, N.D. Isaac [21] при дослідженні трупів виявили некласичний варіант відходження гілок дуги аорти. Першою гілкою відходив спільний сонний стовбур, що давав початок правій загальній сонній і лівій загальній сонній артеріям 3 подальшим нормальним їх галуженням; другою гілкою була ліва підключична артерія із подальшою нормальною топографією; третьою гілкою - права підключична артерія, яка починалася дистальніше лівої підключичної, далі вона проходила позаду стравоходу і сягала правої верхньої кінцівки.

В.С. Аракелян [3] описує проблеми, що стосуються аневризм грудної аорти, особливо їі дуги. Серед аневризм грудної аорти важливе місце посідають уроджені аномалії дуги і низхідної аорти. Особливої уваги потребує вивчення розташування гілок дуги аорти відносно іiї кінкінгу, вірогідність виникнення перетискання артерій, можливість виникнення інтраопераційних ускладнень і переходу на повну гіпотермічну зупинку кровообігу. У своєму дослідженні В.С. Аракелян [13] зазначає, що особливої уваги від спеціалістів при діагностиці вад серцево-судинної системи потребують рідкісні варіанти її будови. У пацієнтів із уродженими вадами дуги аорти важливо оцінити загальний стан, вплив супутніх вад розвитку, наявність коарктаційного синдрому, розвиток аневризм аорти і їі синтопію. У своїх дослідженнях Н.А. Гидаспов [6] дійшов висновку, що аномалії дуги аорти є значним фактором ризику при хірургічних корекціях іншої уродженої патології грудної аорти. Оперативне втручання у пацієнтів із сукупністю аномалії дуги аорти і супутніх уражень грудної аорти супроводжується високим показником летальності (7,89 \%) і частим розвитком ускладнень $(39,5 \%)$, у першу чергу спінальних (15,8 \%) і геморагічних (15,8 \%). При ізольованих аномаліях дуги аорти уроджених захворюваннях грудної аорти з нормальною анатомією дуги летальність становить 0 \%.

\section{Висновок}

Гілки дуги аорти характеризуються досить значною варіабельністю топографії. Можливість атипового відходження гілок дуги аорти слід вра- ховувати при виконанні хірургічних втручань, оскільки існує висока ймовірність їх ушкодження.

\section{Література}

1. Аракелян В.С. Диагностика и непостредственные результаты хирургического лечения врожденных аномалий дуги аорты, приводящих к компрессии трахеи и пищевода / В.С. Аракелян, Н.А. Гидаспов // Бюллетень НЦССХ им. А.Н. Бакулева РАМН «Сердечнососудистые заболевания». - 2007. - Т. 8, № 3. - С. 56.

2. Аракелян В.С. Хирургическая тактика при сочетании аномалий дуги аорты с другими врожденными и приобретенными заболеваниями аорты и ее ветвей / В.С. Аракелян, Н.А. Гидаспов // Бюллетень НЦССХ им. А.Н. Бакулева РАМН «Сердечно-сосудистые заболевания». - 2008. - Т. 9, № 63. - С. 104.

3. Аракелян В.С. Профилактика церебральных осложнений при коррекции врожденной деформации дуги аорты / А.А. Иванов, В.С. Аракелян // Фундаментальные исследования. - 2011. - № 10. - С. 17-21.

4. Вариантная анатомия дуги аорты / О.А. Горустович, Л.В. Бартош, Д.Ю. Дашкевич [и др.] // Сб. трудов науч.-практ. конф. [«Весенние анатомические чтения»], посв. памяти проф. С.С. Усоева (10-11 мая 2012 г.). - Гродно: ГрГМУ, 2012. - С. 22-24.

5. Варианты отхождения ветвей дуги аорты / А.Г. Рыбаков, И.А. Лошкарев, П.А. Мачинский [и др.] // Електронний peсурс. Режим доступу: http:// www.rusnauka.com/27 NII $2013 / \mathrm{Mede}-$ cine/8_145168.doc.htm

6. Гидаспов Н.А. Тактика и непосредственные результаты хирургического лечения пациентов с аномалиями дуги аорты при их сочетании с другими заболеваниями грудной аорты и ее ветвей: автореф. дис. на соискание науч.степени канд. мед. наук: спец. 14.00.44 «Сердечно-сосудистая хиругия» / Н.А. Гидаспов. - М., 2009. - 24 c.

7. Горустович О.А. Вариантная анатомия ветвей дуги аорты / О.А. Горустович, О.М. Волчкевич, Д.А. Волчкевич // Акт. вопр. морфол.: труды Междунар. науч. конф., посв. 100-летию со дня рожд. проф. Б.З. Перлина (Кишинэу, 20-22 сентября 2012 г.). - Кишинэу, 2012. - C. 226-229.

8. Гусь А.С. Морфологические и морфометрические особенности сосудов в области бифуркации общей сонной артерии в зависимости от формы черепа человека / А.С. Гусь, Д.В. Шавлюк // Сб. трудов науч.практ. конф. [«Весенние анатомические чтения»], посв. памяти проф. С.С. Усоева (10-11 мая 2012 г). Гродно: ГрГМУ, 2012. - С. 24-27.

9. Иванов А.А. К вопросу о классификации врожденной деформации дуги аорты / А.А. Иванов, В.С. Аракелян // Фундаментальные исследования. - 2011. - № 11. - C. 42-45.

10. Лужа Д. Рентгеновская анатомия сосудистой системы / Д. Лужа. - Будапешт: Изд-во академии наук Венгрии, 1973. - $380 \mathrm{c}$.

11. Мутафьян О.А. Пороки и малые аномалии сердца у детей и подростков / О.А. Мутафьян. - СПб.: Издательский дом СПбМАПО, 2005. - 480 с.

12. Околокулак Е.С. Особенности строения дуги аорты и её ветвей / В.С. Околокулак, Д.А. Волкевич, Ф.Г. Гаджиева // Акт. пробл. мед.: матер. ежегодной итоговой науч. конф. (Гродно 15-16 декабря 2011 г.) / отв. редактор М.Н. Курбат. - Гродно: ГрГМУ, 2011. С. 429-431.

13. Проблемы диагностики врожденной деформации дуги аорты / В.С. Аракелян, А.А. Иванов, В.Н. Макаренко [и др.] // Вестн. эксперим. и клин. хирургии. - 2010. Т. 3, № 3. - С. 184-190.

14. Соколов Г.А. К анатомии дуги аорты человека и некоторых позвоночных животных: автореф. дис. на соис- 
кание науч. степени канд.мед.наук: спец. 14.03.01 «Нормальная анатомия» / Г.А. Соколов. - Днепропетровск, 1963. - $18 \mathrm{c}$.

15. Хирургическая коррекция врожденной деформации дуги аорты. Клиническое наблюдение / В.С. Аракелян, Н.А. Гидаспов, Н.Р. Гамзаев [и др.] // Креатив. кардиол. - 2015. - № 2. - С. 80-86.

16. Хирургическое лечение врожденной деформации дуги аорты / А.А. Иванов, А.С. Ярощук, Н.А. Гидаспов [и др.] // Бюллетень НЦССХ им. А.Н. Бакулева РАМН «Сердечно-сосудистые заболевания». - 2008. - Т. 9, № 5. - C. 19.

17. Alsaif H.A. An Anatomical Study of the Aortic Arch Variations / H.A. Alsaif, W.S. Ramadan // JKAU: Med. Sci. - 2010. - Vol. 17, № 2. - P. 37-54.

18. Anomalous branching pattern of the aortic arch and its clinical applications / G.L. Shiva Kumar, N. Pamidi, S.N. Somayaji [et al.] // Singapore Med. J. - 2010. Vol. 6. - P. 182-183.

19. Bovine aortic arch variant in humans: clarification of a common misnomer / K.F. Layton, D.F. Kallmes,
H.J. Cloft [et al.] // AJNR Am. J. Neuroradiol. - 2006. Vol. 27 (7). - P. 1541-1542.

20. Branching pattern of aortic arch in a kenyan population / J.A. Ogeng'o, B.O. Olabu, P.M. Gatonga [et al.] // J. Morphol. Sci. - 2010. - Vol. 6. - P. 51-55.

21. Mligiliche N.L. A three branches aortic arch variant with a bi-carotid trunk and a retro-esophageal right subclavian artery / N.L. Mligiliche, N.D. Isaac // International J. of Anatomical Variations. - 2009. - Vol. 6. - P. 11-14.

22. Rekha P. A study on branching pattern of human aortic arch and its variations in south indian population / P. Rekha, S. Senthilkumar // J. Morphol. Sci. - 2013. Vol. 30, № 1. - P. 11-15.

23. Singla R.K. Variant origin of left vertebral artery / R.K. Singla, T. Sharma, K. Sachdeva // International Journal of Anatomical Variations. - 2010. - Vol. 3. P. 97-99.

24. Soubhagya R. Nayak. Anatomical organization of aortic arch variations in the India: embryological basis and review / R. Nayak Soubhagya, M. Pai Mangala // Department of Anatomy, Centre for Basis Sci. - J. Vasc. Bras. 2006. - Vol. 5 (2). - P. 95-100.

\section{СОВРЕМЕННЫЕ ПРЕДСТАВЛЕНИЯ О ВАРИАНТНОЙ АНАТОМИИ ВЕТВЕЙ ДУГИ АОРТЫ (ОБЗОР ЛИТЕРАТУРЫ)}

\section{Т.В. Хмара, Н.А. Базик, Л.Я. Лопушняк}

Резюме. Литературное исследование свидетельствует о выраженной индивидуальной и возрастной анатомической изменчивости ветвей дуги аорты. В статье приведены сведения о врожденной деформации и извилистости дуги аорты, атипичных и редких вариантах топографии ее ветвей, вследствие чего могут возникать компрессионные симптомы, нарушения кровоснабжения соответствующих областей. Возможность атипичного расположения ветвей дуги аорты следует учитывать при проведении хирургических вмешательств, поскольку при этом возникает высокая вероятность их повреждения.

Ключевые слова: дуга аорты, топография, вариантная анатомия, человек.

\section{CURRENT IDEAS ABOUT THE BRANCHES OF THE AORTIC ARCH VARIANT ANATOMY (REVIEW OF THE REFERENCES)}

\section{T.V. Khmara, N.O. Bazik, L.Ya. Lopushniak}

Abstract. The study of literature is indicative of a pronounced individual and age anatomical variability of the branches of the aortic arch. This paper provides information on congenital deformation and tortuosity of the aortic arch, atypical and rare variants of its branches topography, the result of which might be compression symptoms, circulatory disorders of the corresponding areas. The possibility of atypical location of the branches of the aortic arch should be considered during a surgery because in this case there is a high probability of their damage.

Key words: aortic arch, topography, variant anatomy, human.

Higher State Educational Institution of Ukraine "Bukovinian State Medical University" (Chernivtsi)

Рецензент - проф. І.Ю. Олійник
Buk. Med. Herald. - 2016. - Vol. 20, № 3 (79). - P. 219-223

Надійшла до редакції 22.06.2016 року

(C) Т.В. Хмара, Н.О. Базік, Л.Я. Лопушняк, 2016 